\title{
Palm Oil Prediction Production Using Extreme Learning Machine
}

\author{
Yudi Triyanto, Ronal Watrianthos, Pristiyono, Yusmaidar Sepriani, Khairul Rizal
}

\begin{abstract}
The total production of Indonesian palm oil (CPO) in 2018 reached 43.9 million tons, with a land area of 12.3 million hectares. However, every month there are still many companies that have problems in predicting palm oil production. Problems in predicting this production can be solved by calculation methods in the field of artificial neural networks, namely the Extreme Learning Machine (ELM) method. This method can solve linear and non-linear data problems and provide better average computation compared to other methods in predicting oil palm production. The data used is palm oil production data at PT Indo Palm Oil Labuhan Batu with a total of 297 in the period 2017-2018. While the parameters used are planting age, land area, number of trees, and yields. The results of the best-hidden neuron test are 13 with 2 technical data features and the training data pattern is pattern 1 . The average MAPE value is $20.1 \%$ with the fastest computing time is the use of the number of hidden neurons 2 . So based on the test results, the method ELM has a predictive model with quite good performance because the MAPE value is in the range of $20 \%-50 \%$.
\end{abstract}

Index Terms - Extreme Learning Machine, Neural Networks, Palm Oil, Prediction, Production.

\section{INTRODUCTION}

The total production of Indonesian palm oil (CPO) in 2018 reached 43.9 million tons, with a land area of 12.3 million hectares[1][2]. However, every month there are still many companies that have problems in predicting palm oil production. To target production, the company conducts statistical analysts with a correction value of $5 \%-12 \%$ on production each month[3]. This method is not appropriate, because it is not data-based and considers the experience more

Productivity analysis in looking at the factors that influence oil palm growth such as environmental factors, genetic factors, and cultivation techniques is needed to be able to increase productivity in addition to other determinants such as plant age, labor, and rainfall[4].

Problems in predicting this production can be solved by calculation methods in the field of artificial neural networks, namely the Extreme Learning Machine (ELM) method[5]. This method can solve linear and non-linear data problems and provide better average computing than other methods such as Support Vector Machine (SVM) and Artificial Neural Network (ANN). Previous research proves that ELM has superior performance than ANN[6]. Besides, predictions using the ELM method also provide smaller error errors than the ANN and GP methods of 0.0046[7]. Other research also shows that the ELM method has small error values and faster computation than other methods, for example, the backpropagation method. ELM overcomes the problem with the backpropagation algorithm in determining gradients[8].

This study aims to prove whether the ELM method is better at predicting oil palm production. The data used is palm oil production data at PT Indo Palm Oil Labuhan Batu with a total of 297 in the period 2017-2018. While the parameters used are planting age, land area, number of trees, and yields. The value of Mean Absolute Percentage Error (MAPE) will be tested to determine the performance of this method.

\section{Methodology}

This method uses 9 measuring parameters, namely planting age, land area, number of trees, production of the first month, production of the second month, production of the third month, production of the 4th month, production of the 5th month, and target. To perform calculations using the ELM method, the system will receive input data such as production data, number of features, number of neurons in the hidden layer, number of data shares, and types of activation functions.[6]. On production data, the normalization process is carried out to obtain training data and test data. This training data will produce an output weight matrix $(\square)$ and the test data will produce an output layer value (y)[9]. The ELM process will stop after the evaluation results from the

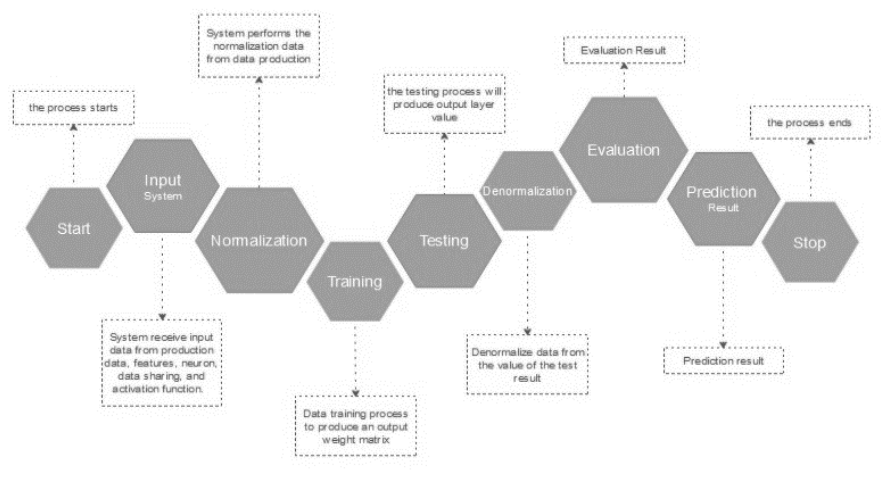

denormalization of the data from the test results. The flow chart in this process is shown in Figure 1.

Fig. 1 Process with Extreme Learning Machine

ELM uses the concept of Single Hidden Layer Feedforward Neural Networks (SLFNs) because it only has 1 hidden layer in its network architecture. ELM method will initialize network parameter values randomly so that network learning time is faster than other methods such as SVM and Backpropagation. Figure 2 shows the ELM network architecture with a computational process in two, namely 
using bias or without bias[10].

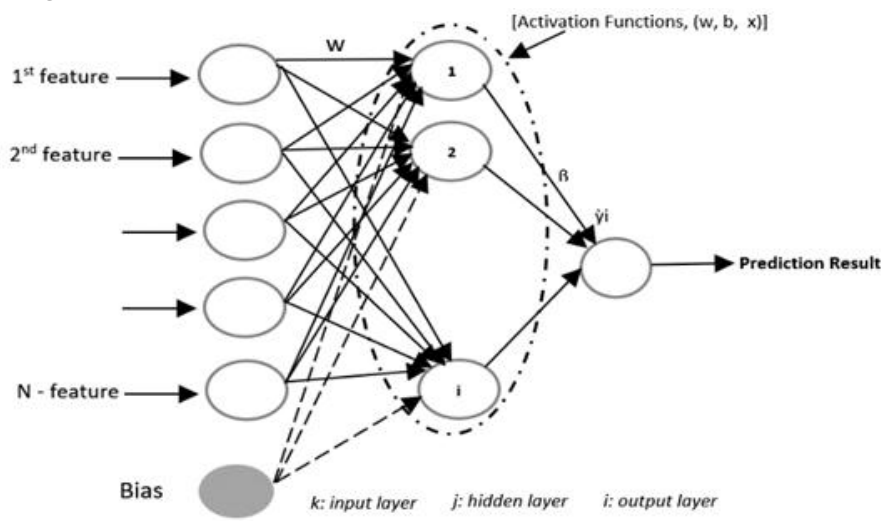

Fig. 2 ELM Architecture with Bias[10]

The use of bias functions to shift the output layer value to the right target. The activation function is used for the process of calculating values and activating or deactivating neurons [10].

\section{RESULT AND DISCUSSION}

\subsection{Testing the Number of Neurons}

The number of neurons was tested to determine the optimal amount to get the smallest Mean Absolute Percentage Error (MAPE) and the number of neurons to computational time. The number of neurons tested is 2 to 15 . The results of testing the number of neurons in the hidden layer are shown in Figures 3 and 4 .

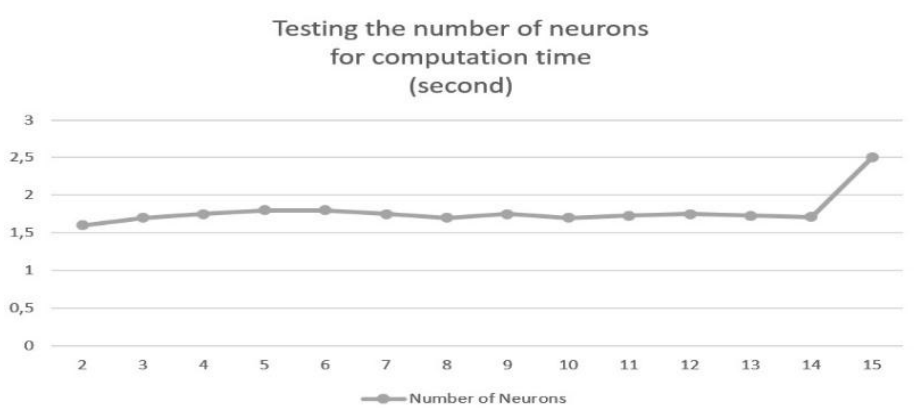

Fig. 3 Neuron Testing Graph

Figure 3 shows the training process resulting in high MAPE results on the results of the test data. Visible neurons that number 2 and 3 produce MAPE as much as $27 \%$. Based on the criteria for the MAPE value, this is categorized quite good, as shown in Table 1[11].

Table. 1 MAPE Value Criteria[11]

\begin{tabular}{cc}
\hline MAPE Value & Status \\
\hline$<10 \%$ & Very Good \\
$10-20 \%$ & Good \\
$20-50 \%$ & Quite Good \\
$>50 \%$ & Poor \\
\hline
\end{tabular}

For a testing computational time, Figure 3 shows the fastest computation time occurs in the number of neurons 2 and the highest computation on 15. neurons In the number of neurons 3 to 14 , the speed of computing time is relatively stable.

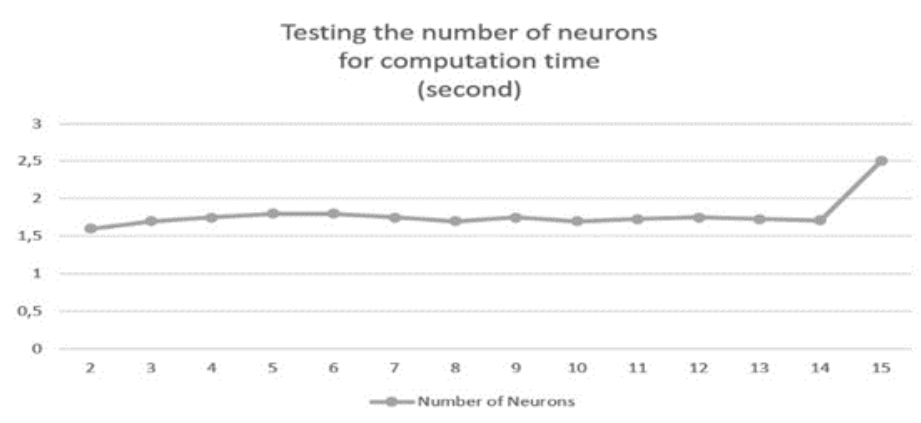

Fig. 4 Neuron Testing Graph Computation Time

\subsection{Testing Number of Features}

This test uses 5 technical data features which are divided into technical data 1, 2, and so on. The other parameter as a benchmark is to use the number of neurons in the hidden layer which amounts to 13. Many or at least the number of features will influence the MAPE value. The lowest average MAPE value occurs in the technical data feature 2 at $20.50 \%$ and the highest at $24.50 \%$ on feature 3 . Based on the graph in Figure 4, the use of technical data is very influential. The best average MAPE value is to use the first-month harvest data analysis and the second from the month to be predicted.

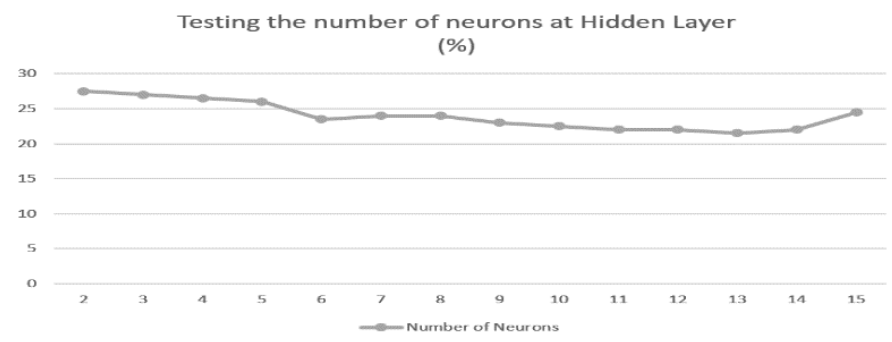

Fig. 5 Testing Data Technical Feature

\subsection{Data Pattern Testing}

Data pattern testing was done in 2 ways, namely in the data pattern with many years of planting in one month and data patterns with many months in one planting year. Tests are carried out using the number of 13 neurons with 2 technical data features.

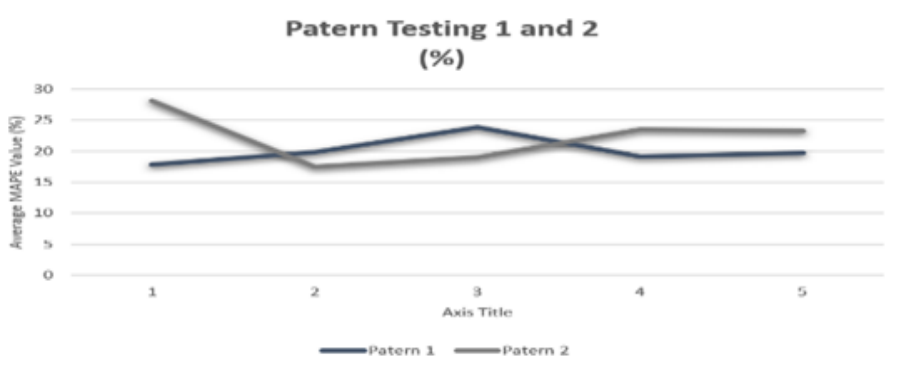

Fig. 6 Pattern Testing 1 and 2

Based on Figure 6, the result of pattern 2 has a higher MAPE value of $28 \%$ compared to pattern 1 with a value of $23 \%$. This result is because pattern 2 has several patterns of test data that are not recognized in the training data. Also, there are underfitting conditions in some data due to the process of training data, the network cannot capture the relationship between the input signal and the target due to the lack of the 
number of neurons in the hidden layer.

\section{Conclusions}

This research shows that the Extreme Learning Machine (ELM) method can produce optimal calculation features in the computation process. The results of the best-hidden neuron test are 13 with 2 technical data features and the training data pattern is pattern 1 . The average MAPE value is $20.1 \%$ with the fastest computing time is the use of the number of hidden neurons 2. So based on the test results, the method ELM has a predictive model with quite good performance because the MAPE value is in the range of $20 \%-50 \%$.

\section{REFERENCES}

[1] D. J. P. K. Pertanian, "Volume produksi kelapa sawit (CPO), 2000-2018," 2018. [Online]. Available: https://lokadata.beritagar.id/chart/preview/volumeproduksi-kelapa-sawit-cpo-2000-2018-1550473390.

[Accessed: 05-Jul-2019].

[2] Directorate General of Estate Crops, "Tree Crop Estate Statistik of Indonesia (2005-2017 Palm Oil)," 2017.

[3] E. Agasta, I. Cholissodin, and D. E. Ratnawati, "Prediksi Jumlah Produksi Kelapa Sawit Dengan Menggunakan Metode Extreme Learning Machine ( ELM ) ( Studi kasus® : PT . Sandabi Indah Lestari Kota Bengkulu )," J. Pengemb. Teknol. Inf. dan Ilmu Komput., vol. 2, no. 11, pp. 5751-5759, 2018.

[4] W. M. Yohansyah and I. Lubis, "Analisis Produktivitas Kelapa Sawit (Elaeis guineensis Jacq.) di PT. Perdana Inti Sawit Perkasa I, Riau," Bul. Agrohorti, vol. 2, no. 1, p. $125,2018$.

[5] S. Ding, H. Zhao, Y. Zhang, X. Xu, and R. Nie, "Extreme learning machine: algorithm, theory and applications," Artif. Intell. Rev., vol. 44, no. 1, pp. 103$115,2015$.

[6] A. N. Alfiyatin, W. F. Mahmudy, C. F. Ananda, and Y. P. Anggodo, "Penerapan Extreme Learning Machine (ELM) untuk Peramalan Laju Inflasi di Indonesia," J. Teknol. Inf. dan Ilmu Komput., vol. 6, no. 2, p. 179, 2019.

[7] B. Wang, "Prediction of Fatigue Stress Concentration Factor Using Extreme Learning Machine," Comput. Mater. Sci., vol. 125, pp. 136-145, 2016.

[8] V. Sari, "Aplikasi Extreme Learning Machine Untuk Peramalan Data Time Series," 5TH URECOL PROCEEDING, vol. 5, no. February, pp. 1294-1299, 2017.

[9] L. Yibo, L. Fang, and C. Qi, "A Review of the Research on the Prediction Model of Extreme Learning Machine," J. Phys. Conf. Ser., vol. 1213, p. 042013, 2019.

[10] Z. M. Yaseen, "Predicting Compressive Strength of Lightweight Foamed Concrete Using Extreme Learning Machine Model," Adv. Eng. Softw., vol. 115, pp. 112-115, 2018.

[11] P.-C. Chang, Y.-W. Wang, and C.-H. Liu, "The
Development of a Weighted Evolving Fuzzy Neural Network for PCB Sales Forecasting," Expert Syst. Appl., vol. 32, pp. 88-89, 2007. 